\title{
Essential metal contents in indigenous gammarids related to exposure levels at the river basin scale: Metal-dependent models of bioaccumulation and geochemical correlations
}

\author{
Jérémie D. Lebrun ${ }^{\mathrm{a}, \text { * }}$, Emmanuelle Uher ${ }^{\mathrm{a}}$, Marie-Hélène Tusseau-Vuillemin ${ }^{\mathrm{b}}$, \\ Catherine Gourlay-Francé ${ }^{a}$
}

\author{
a Irstea, UR HBAN-Ecotoxicology, 1 Rue Pierre-Gilles de Gennes, 92761 Antony, France \\ ${ }^{b}$ IFREMER, 155 Rue Jean-Jacques Rousseau, 92138 Issy-Les-Moulineaux, France \\ *: Corresponding author : Jérémie D. Lebrun, tel.: + 33140966163 ; fax: + 33140966199 ; email address : \\ jeremie.lebrun@irstea.fr
}

\begin{abstract}
:
Biomonitoring, assumed to be an integrative measurement of the chemical exposure of aquatic organisms, is not straightforward for essential metals because they can be actively regulated by animals. Although increasing bioaccumulation with exposure levels is a crucial endpoint for the development of biomonitors, it is rarely verified in real environments, where the metal concentrations are rather low and vary little. This study was designed at the scale of a river basin to assess the ability of Gammarus pulex indigenous populations to accumulate $\mathrm{Cu}, \mathrm{Zn}$ and $\mathrm{Mn}$ in realistic exposure conditions. During two annual campaigns, water and gammarids were collected at various sites contrasted in terms of physicochemistry and contamination. The results show significant relationships between metal concentrations in animals and in freshwaters established by conceptual models of bioaccumulation, but with patterns specific to each metal (base level, internal regulation and maximal accumulation). In particular, a saturation process of $\mathrm{Cu}$ accumulation occurs at environmental exposure levels, unlike $\mathrm{Mn}$ and $\mathrm{Zn}$. Statistical analyses performed from field data show that $\mathrm{Cu}$ and $\mathrm{Zn}$ bioaccumulations may be influenced by a complex combination of geochemical variables, unlike $\mathrm{Mn}$. We conclude that $G$. pulex is a useful candidate to monitor metal bioavailability in freshwaters due to its responsiveness to low exposures of surrounding environments. Nevertheless, a reliable quantification of bioavailability of essential metals requires characterizing some geochemical effects on metal bioaccumulation.
\end{abstract}

\section{Highlights}

- $\mathrm{Cu}, \mathrm{Zn}$ and $\mathrm{Mn}$ accumulations by gammarids are assessed in realistic exposure conditions. Indigenous populations were sampled in many contrasted freshwaters at the basin scale. Metal contents in gammarids increase with freshwater contamination levels. Bioaccumulation is modeled according to patterns specific to each essential metal. Statistical analyses report geochemical correlations to $\mathrm{Cu}$ and $\mathrm{Zn}$ bioaccumulations.

Keywords: Biomonitor ; Metal bioavailability ; Gammarus pulex ; Copper ; Zinc ; Manganese 


\section{Introduction}

Many metals occurring in freshwaters such as $\mathrm{Cu}, \mathrm{Zn}$ and $\mathrm{Mn}$ are essential for living organisms. However, human activities (agricultural practices, urban effluents, mining for industrial applications, etc.) lead to their significant discharge into the aquatic environment, modify their distribution and speciation towards chemical forms that are more mobile for biota (Thevenot et al., 2007). Therefore, excessive inputs of these non-degradable contaminants exert toxic effects on aquatic organisms, affect biodiversity and disturb ecosystem functioning. At the individual level, essential metal exposures may alter biological functions such as osmoregulation, growth, reproduction or digestive metabolism as reported in fish or invertebrates (Atli and Canli, 2011; Lebrun et al., 2012; Peters et al., 2011). The contamination of freshwaters by $\mathrm{Cu}$ reduces the decomposition of leaf litter by affecting the macroinvertebrate community structure (Roussel et al., 2008). Considering the harmful effects of essential metals, the study of relevant indicators of exposure is of a great interest for environmental risk assessment (Besse et al., 2012).

Because of their ecological relevance, the European Water Framework Directive (WFD) recommends biomonitoring approaches for better expertise in chemical contamination of water (Directive 2008/105/EC). Indeed, the bioaccumulation process integrates the exposure of organisms, their ability to regulate accumulated metals and geochemical effects on metal uptake (Luoma and Rainbow, 2005; McGeer et al., 2003). Metal determination in animal bodies is thus assumed to be an integrative tool to monitor metal bioavailability, based on the fraction potentially toxic for biota. Nevertheless, to be a useful indicator, metal contents in biological tissues must increase with exposure levels (Fialkowski and Rainbow, 2006). In all aquatic species, essential metals are required at base levels for their biological needs, i.e. metabolic functions and a variety of enzymes (Baden and Eriksson, 2006; Rainbow, 2007). To prevent toxic damage caused by an excess of internalized metals, animals eliminate metals through gills and have detoxifying mechanisms such as intracellular sequestration (e.g. metallothioneins) or binding with metal-rich granules released into the gut lumen, as described in invertebrates (Khan et al., 2012; Rainbow, 2007). In addition, some crustaceans actively regulate essential metal contents to maintain them at constant levels by increasing turnover or decreasing uptake, as shown in Daphnia magna acclimated to environmentally realistic $\mathrm{Cu}$ concentrations (Bossuyt and Janssen, 2005). Such regulation systems may negate a net accumulation of essential metals above their base levels, especially in real environments often only slightly contaminated, which constitutes a selection criterion in the choice of organisms to use as biomonitors.

Among aquatic species, gammarids are ubiquitous in European freshwaters and easily sampled in the field. These amphipods play important ecological roles as a link between the base of food webs, as litter degraders, and higher-order consumers, as food for fish and birds (Roussel et al., 2008). Also, net accumulations of metals, whether or not they are essential, have been reported in various species of gammarids such as Gammarus pulex or G. fossarum (Geffard et al., 2010; Lebrun et al., 2011; Pellet et al., 2009). In laboratory conditions, internal contents increased with increasing exposure concentrations for essential metals such as $\mathrm{Cu}, \mathrm{Zn}$ and Fe in G. pulex (Lebrun et al., 2012; Maltby and Crane, 1994). Such relationships remain to be verified in the field to assess the relevance of using gammarids as indicators of exposure to essential metals.

To date, field data on bioaccumulation are limited for crustaceans and overall are scarce for continental environments due to their complexity and variability (Besse et al., 2012). Even more, the high variability in chemical composition between freshwaters can hamper the interpretation of bioaccumulation data insofar as parameters such as $\mathrm{Na}, \mathrm{Mg}, \mathrm{Ca}$ and $\mathrm{pH}$ are known to affect metal uptake in crustaceans (Komjarova and Blust, 2009; Verschoor et al., 2012). Furthermore, biomonitoring investigations are generally achieved at the scale of a 
single freshwater body exhibiting a high contamination gradient (Fialkowski and Rainbow, 2006; Khan et al., 2011; Maltby and Crane, 1994). Hence, very few studies consider both the low levels of contamination and physicochemical heterogeneity of freshwaters on a large scale.

This study was designed on a large spatial scale to investigate i) the ability of indigenous populations of $\mathrm{G}$. pulex to accumulate $\mathrm{Cu}, \mathrm{Zn}$ and $\mathrm{Mn}$ at environmentally relevant exposure levels and ii) the potential of this species as a biomonitor of metal contamination from heterogenic freshwaters. During two annual monitoring campaigns, water and gammarids were collected on 64 sites in the Seine basin, representative of media multi-contaminated by metals at a low level (Thevenot et al., 2007). Four sampling sites were conserved from one year to the next for inter-annual comparisons. We chose to use size-calibrated organisms sampled during a single season to minimize physiological effects on bioaccumulation (Verschoor et al., 2012). To relate data bioaccumulation to metal contamination levels of freshwaters, we used two conceptual models commonly applied in the literature, the biodynamic and saturation models (Borgmann et al., 2004; Luoma and Rainbow, 2005). Statistical analyses were also performed to identify the main physicochemical variables likely to influence metal bioaccumulation based on field data.

\section{Material and methods}

\subsection{Study area and sample collection}

The Seine River basin covers $68000 \mathrm{~km}^{2}$ with approximately 16 million inhabitants (i.e. about $25 \%$ of the French population) (Fig. 1). The Seine crosses the Paris megacity with its very high population density (220 people $\mathrm{km}^{2}$ ) and significant industrial activities resulting in metal discharges from urban, domestic and industrial effluents. In addition, this basin hosts about $30 \%$ of French manufactures (energy transformation, manufacturing, etc.) and an important road network leading to metal emissions and fallouts. The main tributaries of the Seine are the Marne, the Yonne and the Oise, which drain intensive agricultural areas (cereal crops and vineyards in the east of basin). These areas receive amendments of fertilizers, organic wastes and pesticides, contributing metal inputs to the aquatic environment including essential metals (Thevenot et al., 2007; Tusseau-Vuillemin et al., 2007).

Water and indigenous populations of gammarids were collected during two French WFD monitoring campaigns: 37 sites in summer 2008 and 27 sites in summer 2009 (Fig. 1). These sites were chosen because they are routinely monitored in terms of physicochemistry by a French public company (Agence de l'Eau de Seine-Normandie). Sampling done on freshwaters exhibiting both different contamination levels and physicochemical properties covered a large spatial scale (more $75 \mathrm{~km}$ surrounding Paris). Four sampling sites were preserved from 1 year to the next for inter-annual comparisons.

On each sampling site, approximately 50 adult gammarids were selected according to their body diameter using a series of sieves: those that passed through a $2.5-\mathrm{mm}$, but not a 2-mm sieve; i.e. the length of animals was about $1 \mathrm{~cm}$. Then, the animals were transported in pails of local water, introduced in cool box for return to the laboratory. For total metal fraction, 50 $\mathrm{mL}$ of raw water was sampled in polypropylene tubes (SCP Science). For dissolved metal fraction, $30 \mathrm{~mL}$ of raw water was filtered through $0.45-\mu \mathrm{m}$ PES syringe filter (Millipore) and transferred to $50-\mathrm{mL}$ polypropylene tubes. 


\subsection{Analytical procedures}

In the laboratory, ten individuals for each gammarid sample were used for taxonomic identification in order to keep only indigenous populations mainly represented by the G. pulex species (> 70\%). This identification led to keeping 24 sites out of 37 for the 2008 campaign and 14 sites out of 27 for the 2009 campaign. The gammarids of these sites were distributed into 3 or 4 pools with 10 individuals each in $50-\mathrm{mL}$ polypropylene tubes (SCP Science), lyophilized for $24 \mathrm{~h}$, weighted and digested by adding nitric acid and hydrogen peroxide as described by Pellet et al. (2009). Mineralized samples were analysed by inductively coupled plasma mass spectrometry or ICP-MS (X series 2, Thermo Fisher Scientific) to determine $\mathrm{Cu}, \mathrm{Zn}$ and $\mathrm{Mn}$ concentrations in the animal bodies. The digestion method was successfully validated by a reference material (Mussel Tissue ERM-CE278).

For total metal determination, raw water was acidified with $\mathrm{HNO}_{3}$ at $1 \% \mathrm{v} / \mathrm{v}$ and mineralized by treatment with $\mathrm{HNO}_{3}$ and $\mathrm{HCl}$ on a hotblock (Digiprep, SCP Science) following an adaptation of the US EPA 3010A method (Uher et al., 2011). For dissolved metal determination, water filtrates were acidified in the laboratory with $\mathrm{HNO}_{3}$ at $0.1 \% \mathrm{v} / \mathrm{v}$. Total and dissolved water samples were stored at $4^{\circ} \mathrm{C}$ until they were analysed by ICP-MS to determine $\mathrm{Cu}, \mathrm{Zn}$ and $\mathrm{Mn}$ concentrations in freshwaters. The detection limits for $\mathrm{Cu}, \mathrm{Zn}$ and $\mathrm{Mn}$ were $0.01,0.50$ and $0.15 \mu \mathrm{g} / \mathrm{L}$ respectively and recoveries of standards (NIST 1640) were within $95-107 \%$.

\subsection{General water chemistry}

The physicochemical values of freshwaters were taken from the Agence de l'Eau de SeineNormandie (http://www.eau-seine-normandie.fr). This French public company periodically performs routine chemical monitoring following normalized procedures on most of the sampling sites (ISO or NF EN ISO methods). From this public database, we selected $\mathrm{pH}$, temperature, conductivity and major ions found in freshwaters $\left(\mathrm{Ca}, \mathrm{Mg}, \mathrm{Na}, \mathrm{K}, \mathrm{Cl}, \mathrm{CO}_{3}\right.$ and $\mathrm{SO}_{4}$ ) in accordance with the sampling dates.

\subsection{Bioaccumulation models}

Two biology-based conceptual models, the biodynamic and saturation models, were used to fit bioaccumulation data to metal concentrations in water. According to the biodynamic model, the metal concentration in an organism results from a balance of unidirectional fluxes (Luoma and Rainbow, 2005). Assuming that the predominant exposure route of organisms is water (Baden and Eriksson, 2006; Xu and Pascoe, 1994), the metal bioaccumulation at steady state is proportional to metal concentration in water as follows:

$$
C_{s s}=\frac{k_{u}}{k_{e}} C_{w}+C_{O}
$$

where $C_{s s}$ is the amount of metal in gammarids at steady state $\left(\mu \mathrm{g} / \mathrm{g}_{\text {dry weight }}\right), C_{w}$ is the metal concentration in water $(\mu \mathrm{g} / \mathrm{L}), C_{0}$ is the base level of metal in gammarids $\left(\mu \mathrm{g} / \mathrm{g}_{\mathrm{dw}}\right), k_{u}$ is the uptake rate constant $(\mathrm{L} / \mathrm{g} / \mathrm{d})$ and $k_{e}$ is the elimination rate constant $(1 / \mathrm{d})$.

Based on Michaelis-Menten kinetics, the saturation model considers that the organism cannot infinitely accumulate metals due to a limited number of binding sites in the whole of the animal body (Borgmann et al., 2004). Thus, it describes metal bioaccumulation as follows:

$$
C_{s s}=\frac{B_{\max } C_{w}}{K+C_{w}}+C_{O}
$$


where $B_{\max }$ is the maximum capacity of the animal to bind the metal at the specific sites $\left(\mu \mathrm{g} / \mathrm{g}_{\mathrm{dw}}\right)$ and $K$ is the half-saturation constant $(\mu \mathrm{g} / \mathrm{L})$.

\subsection{Calculations and statistical analyses}

In field studies, the determination of bioaccumulation factor (BAF) is commonly used to predict partitioning of contaminants between exposure medium and biota (McGeer et al., 2003; Verschoor et al., 2012). For each sampling site, BAFs were calculated as the ratios of metal concentration in animals to metal concentration in freshwaters, expressed in $\mathrm{L} / \mathrm{kg}$ of dry weight. Plotting BAFs versus exposure levels of gammarids were performed on log-log basis.

For interannual comparisons, we determined the differences of contamination levels of gammarids and freshwaters between 2008 and 2009 campaigns. Linear regressions between inter-annual differences of contamination levels of gammarids and those of waters were performed for each essential metal and tested with $P<0.05$.

Fitting bioaccumulation models (Eqs. 1 and 2) on field data were performed using XLStat (Addinsoft). Parameters of models and base levels established by the statistical program were reported with standard errors. To determine net accumulations above base levels, metal concentrations in gammarids measured on each site were compared to base levels calculated by bioaccumulation models through the $t$-test $(P<0.05)$.

The effects of physicochemical properties of freshwaters on metal bioaccumulation were assessed by a multiple correlation analysis from 31 of 38 sites studied in two sampling campaigns, for which physicochemical data were available. This statistical analysis consisted on obtaining Pearson correlation coefficients (PCC) between internal contents of essential metals and all considered geochemical variables. The positive or negative significance of PCC was tested with $P<0.05$.

\section{Results and Discussion}

\subsection{Metal contamination of freshwaters}

At the scale of the Seine basin, the ranges of metal concentrations in freshwaters collected during the two sampling campaigns were 0.3-12.6, 2.6-107.4 and 6.4-209.2 $\mu \mathrm{g} / \mathrm{L}$ for total $\mathrm{Cu}, \mathrm{Zn}$ and $\mathrm{Mn}$, and $0.2-5.3,1.0-52.3$ and $2.2-128.4 \mu \mathrm{g} / \mathrm{L}$ for dissolved $\mathrm{Cu}, \mathrm{Zn}$ and $\mathrm{Mn}$ (Fig. 2A). Total and dissolved concentrations of each metal were widely distributed, with a high spatial variability between sampling sites, in accordance with the ranges established from 43 different sites also sampled at the Seine basin scale (Uher et al., 2011). In our study, averages of dissolved concentrations were $1.1 \mu \mathrm{g} / \mathrm{L}$ for $\mathrm{Cu}, 6.0 \mu \mathrm{g} / \mathrm{L}$ for $\mathrm{Zn}$ and $15.9 \mu \mathrm{g} / \mathrm{L}$ for $\mathrm{Mn}$. These values are included in the world averages established from rural river systems (Gaillardet et al., 2004), except for Zn which was 10 times higher in the Seine basin.

Despite their potential adverse effects for biota, essential metals are not referenced as priority substances singled out by the European WFD, unlike $\mathrm{Pb}, \mathrm{Cd}, \mathrm{Hg}$ and $\mathrm{Ni}$ (Directive 2008/105/EC). Presently, European regulations face the problem of taking into account the naturally occurring background concentrations in the derivation of EQSs for essential metals. Indeed, this determination of background concentrations is complex because of their essential character for biota, the great viability of geochemical backgrounds from one freshwater system to another and the difficulty to determine the contribution of anthropogenic inputs of essential metal in aquatic environments (Comber et al., 2008; Peters et al., 2011). 
Nevertheless, provisional Environmental Quality Standards (EQSs) for the protection of aquatic ecosystems have been proposed for dissolved $\mathrm{Cu}$ and $\mathrm{Zn}$ in surface waters, which are 1.4 and $7.8 \mu \mathrm{g} / \mathrm{L}$, respectively. French regulation has also proposed a predicted no-effect concentration for aquatic life of $15 \mu \mathrm{g} / \mathrm{L}$ for dissolved Mn (Bisson et al., 2011). In this study, 33, 56 and $38 \%$ of sampling sites exceeded these absolute threshold values for dissolved $\mathrm{Cu}, \mathrm{Zn}$ and $\mathrm{Mn}$, respectively. This provides insight into the applicability of such provisional EQSs on field data and the proportion of sites potentially harmful for aquatic life at the basin scale.

\subsection{Metal concentrations in gammarids}

From the best fits of bioaccumulation data on total or dissolved metals in waters (Fig. 3), obtained base levels were $53.3 \pm 6.5$ or $55.6 \pm 7.3 \mu \mathrm{g} / \mathrm{g}_{\mathrm{dw}}$ for $\mathrm{Cu}, 75.6 \pm 5.5$ or $75.5 \pm 3.1$ $\mu \mathrm{g} / \mathrm{g}_{\mathrm{dw}}$ for $\mathrm{Zn}$ and $11.0 \pm 12.3$ or $25.9 \pm 15.0 \mu \mathrm{g} / \mathrm{g}_{\mathrm{dw}}$ for $\mathrm{Mn} \mu \mathrm{g} / \mathrm{g}_{\mathrm{dw}}$. These values were in accordance with those recorded in populations of $G$. pulex from unimpacted environments (Khan et al., 2011; Maltby and Crane, 1994; Xu and Pascoe, 1994). As in all living organisms, essential metals are required in minimal amounts in crustaceans to meet their biological needs, but these amounts vary according to both the biological species and the metal considered (Rainbow, 2007). The present results suggest that the internal requirements for $\mathrm{Mn}$ are at least twofold lower than those for $\mathrm{Cu}$ or $\mathrm{Zn}$ in G. pulex. Indeed, $\mathrm{Cu}$ and $\mathrm{Zn}$ are known to be structural or catalytic components for a variety of proteins and enzymes and are involved in osmoregulation or other biological functions of aquatic organisms. In particular, $\mathrm{Cu}$ is a functional part of the respiratory protein haemocyanin in crustaceans (Rainbow, 2007; Shuhaimi-Othman et al., 2012). Unlike Cu and Zn, the importance of $\mathrm{Mn}$ in biological functions is still not clearly identified in crustaceans, but it is known to be a cofactor in some enzymatic reactions (Baden and Eriksson, 2006).

At the scale of the Seine basin, the ranges of metal concentrations in G. pulex were 41.1$110.4 \mu \mathrm{g} / \mathrm{g}$ for $\mathrm{Cu}, 62.8-128.7 \mu \mathrm{g} / \mathrm{g}$ for $\mathrm{Zn}$ and $9.0-571.0 \mu \mathrm{g} / \mathrm{g}$ for $\mathrm{Mn}$ (Fig. 2B). The variations within these ranges confirmed that gammarids accumulate essential metals above base levels when exposed to environmental concentrations. Indeed, more than $69 \%$ of internal contents were significantly higher than base levels for $\mathrm{Cu}$ and $\mathrm{Mn}$, and $43 \%$ for $\mathrm{Zn}$. In crustaceans, net accumulations occur when metal uptake exceeds excretion mechanisms combined with their ability to store metals under detoxified forms (Geffard et al., 2010; Rainbow, 2007). In particular, G. pulex has been shown to sequestrate internalized Cu and $\mathrm{Zn}$ thanks to the synthesis of low-molecular-weight proteins with high affinity for metals, i.e. metallothioneins, or the formation of insoluble metal-rich granules (Khan et al., 2012). Thus, the non-maintenance of essential metal contents to constant levels in G. pulex for environmental exposures argues in favour of its use as biomonitor.

However, the ranges of metal contents in gammarids were much less extensive for $\mathrm{Cu}$ and $\mathrm{Zn}$ than for $\mathrm{Mn}$, whereas there was a great variability of contamination levels in freshwaters for each metal (Figs. 2A vs. 2B). These results suggest that gammarids control an excess of internalized $\mathrm{Cu}$ and $\mathrm{Zn}$ more efficiently than $\mathrm{Mn}$. It is possible that gammarids modulate some regulation mechanisms so that $\mathrm{Cu}$ and $\mathrm{Zn}$ are within physiologically accepted levels. Indeed, $\mathrm{Cu}$ contents have been shown to be actively regulated by increasing turnover or decreasing uptake in the crustacean D. magna (Bossuyt and Janssen, 2005). Especially, a decrease in $\mathrm{Cu}$ uptake with increasing exposure concentrations has been showed in $G$. pulex (Lebrun et al., 2012). Furthermore, crustaceans including G. pulex can eliminate stored metals by release of metal-rich granules into the gut lumen during their feeding (Rainbow, 2007). 


\subsection{Bioaccumulation factors}

Our field data showed that the indigenous populations of $G$. pulex concentrate $\mathrm{Mn}, \mathrm{Cu}$ and $\mathrm{Zn}$ in their tissues for the levels of environmental exposures, but to different degrees. Indeed, essential metals were concentrated in gammarids in this order: $\mathrm{Cu}>\mathrm{Zn}>\mathrm{Mn}$ with average BAFs of $31,550,8,980$ and $2,980 \mathrm{~L} / \mathrm{kg}$ of dry weight, respectively. Such an order for these essential metals has also been established in freshwater snails and in marine and estuarine amphipods under laboratory conditions (Clason and Zauke, 2000; Shuhaimi-Othman et al., 2012).

Plotting BAFs versus exposure levels of indigenous gammarids is presented in Fig. 4. For $\mathrm{Mn}$, no significant relationship was established between BAFs and exposure levels. For $\mathrm{Cu}$ and $\mathrm{Zn}$, BAFs were greatly and negatively related to metal concentrations in freshwaters $\left(\mathrm{R}^{2}\right.$ $=0.94$ and 0.97 ), confirming the ability of $G$. pulex to regulate actively these elements. Such negative relationships were reported in various aquatic animals including $G$. pulex, which could be explained by a decrease in the uptake of these essential metals at high exposure concentrations (Lebrun et al., 2012; McGeer et al., 2003). Since the ability of G. pulex to concentrate metals in its tissues varies with exposure levels, BAFs commonly used in the literature as the most simplified empirical model for hazard identification of contaminants, appear to be inappropriate in the case of $\mathrm{Cu}$ and $\mathrm{Zn}$.

\subsection{Annual variations in contamination levels}

It is known that seasons influence the physiology and generation replacement of aquatic organisms and thus their response to metal exposures (Fialkowski et al., 2003; Verschoor et al., 2012). To minimize seasonal and physiological effects that may affect the bioaccumulation process, inter-annual field comparisons were conducted in the same season and with size-calibrated gammarids. Annual variations in total metal concentrations in $G$. pulex populations and in waters collected from four small tributaries of the Seine basin during summers 2008 and 2009 (see Fig. 1) are presented in Fig. 5.

Linear regressions between inter-annual differences of contamination levels of gammarids and those of waters revealed a significant relation only for $\mathrm{Mn}$ (slope $=2.15 \pm 0.45 ; R^{2}=0.92$ with $P<0.05$ ). For $\mathrm{Cu}$, although the field data seem to indicate that the contamination levels of gammarids followed the same trends as those of freshwaters, they were not significant $\left(R^{2}\right.$ $=0.54$; with $P<0.5$ ). For $\mathrm{Zn}$, the absence of relations was likely due to the fact that no internal concentrations were significantly different from base level, suggesting an active regulation by gammarids or low bioavailabilities of $\mathrm{Zn}$ on the sampling sites. In conclusion, populations of gammarids acclimated to local physicochemical conditions are responsive to low temporal fluctuations of exposures occurring in their surrounding environments in the case of $\mathrm{Mn}$, which remains to be confirmed in the case of $\mathrm{Cu}$ and $\mathrm{Zn}$. Nevertheless, significant changes in internal contents of these essential metals have been observed in indigenous populations of the amphipod Talitrus saltator during interannual comparisons (Fialkowski et al., 2003).

\subsection{Relationships between metal concentrations in gammarids and in waters}

Essential metals have been shown to be mainly accumulated from water rather from food in crustaceans including G. pulex (Baden and Eriksson, 2006; Borgmann et al., 2007; Xu and Pascoe, 1994). Based on the assumption that water is the predominant route of contamination of the indigenous populations of $G$. pulex, two conceptual models, the biodynamic and saturation models, were used to describe the bioaccumulation of essential 
metals from water-only exposures. The best fittings of the bioaccumulation models on the data field are given in Fig. 3.

The saturation model defined by a hyperbolic relationship gave a better estimation of $\mathrm{Cu}$ bioaccumulation in indigenous gammarids than the biodynamic model. The parameters obtained by fitting Eq. (2) on the bioaccumulation data were $B_{\max }=73.3 \pm 11.1 \mu \mathrm{g} / \mathrm{g}_{\mathrm{dw}}$ and $\mathrm{K}$ $=3.7 \pm 1.2 \mu \mathrm{g} / \mathrm{L}$ versus total $\mathrm{Cu}$ in waters $\left(R^{2}=0.61\right)$ and $B_{\max }=63.3 \pm 12.7 \mu \mathrm{g} / \mathrm{g}_{\mathrm{dw}}$ and $K=$ $1.1 \pm 0.5 \mu \mathrm{g} / \mathrm{L}$ versus dissolved $\mathrm{Cu}$ in waters $\left(\mathrm{R}^{2}=0.43\right)$. For comparison, fitting the biodynamic model (Eq. 1) on bioaccumulation data versus total or dissolved $\mathrm{Cu}$ in waters gave $k_{u} / k_{e}$ ratios of $3.8 \pm 0.7$ and $8.1 \pm 2.4 \mathrm{~L} / \mathrm{g}$ as slopes of linear relationships $\left(R^{2}=0.38\right.$ and 0.24 , respectively).

The saturation model has also been reported as being more suitable than the biodynamic model to describe $\mathrm{Cu}$ bioaccumulation in freshwater snails and $\mathrm{H}$. azteca (Borgmann et al., 2004; Croteau and Luoma, 2007). This is explained by the fact that metal uptake tends to saturate for elevated exposure concentrations because the number of binding sites for the metal becomes limited. The best prediction of $\mathrm{Cu}$ bioaccumulation by the saturation model in G. pulex has been demonstrated in laboratory conditions insofar as the saturation process occurred at environmental exposure levels (Lebrun et al., 2012). Indeed, the values of the half-saturation constant established in this study $(K=3.7$ and $1.1 \mu \mathrm{g} / \mathrm{L}$ for total and dissolved $\mathrm{Cu}$ ) are within the ranges of $\mathrm{Cu}$ contamination levels measured in the Seine basin freshwaters (Fig. 2A).

Bioaccumulations of $\mathrm{Zn}$ and $\mathrm{Mn}$ in indigenous populations were satisfactorily described by the biodynamic model (Eq. 1). Thus, steady-state Mn concentrations in gammarids were highly related to total and dissolved $\mathrm{Mn}$ in freshwaters, with $k_{u} / k_{e}$ ratios of $3.5 \pm 0.4$ and $2.4 \pm$ $0.2 \mathrm{~L} / \mathrm{g}$, respectively $\left(\mathrm{R}^{2}=0.76\right.$ and $\left.0.62 ; P<0.001\right)$. Insofar as the higher points could drive these regressions, data were plotted on a log-log basis to minimize their influence. Despite a decrease in regression coefficients, we confirmed the significant linear relationships between $\mathrm{Mn}$ in animals and exposure levels for total and dissolved $M n\left(R^{2}=0.57\right.$ and 0.41 ; with $P<$ 0.001). To a lesser extent, $\mathrm{Zn}$ bioaccumulation was significantly related to total and dissolved $\mathrm{Zn}$ in freshwaters, with $k_{u} / k_{e}$ ratios of $1.1 \pm 0.3$ and $0.5 \pm 0.1 \mathrm{~L} / \mathrm{g}$, respectively $\left(\mathrm{R}^{2}=0.25\right.$ and $0.30 ; P<0.05)$. These values for $\mathrm{Zn}$ are on the same order of magnitude as the value established in H. azteca, i.e. $1.5 \mathrm{~L} / \mathrm{g}$ (Borgmann et al., 2004). Low correlations between $\mathrm{Zn}$ bioaccumulation and concentrations in waters have also been reported in eight species groups including amphipods, due to both an active regulation of this essential metal and a very slight uptake of $\mathrm{Zn}$ by aquatic animals, even over a dramatic increase in exposure concentration (McGeer et al., 2003).

Inappropriate fitting of the saturation model on the bioaccumulation field data is likely caused by half-saturation constants that greatly exceed the contamination levels measured in the environment. For example, $K$ values established in $H$. azteca were greater than 150 and $1150 \mathrm{\mu g} / \mathrm{L}$ for $\mathrm{Zn}$ and Mn, respectively (Borgmann et al., 2004; Norwood et al., 2006). Hence, at levels of environmental contamination, the prediction of $\mathrm{Mn}$ and $\mathrm{Zn}$ bioaccumulation by the biodynamic or saturation model is comparable since these models share a common linear part for the lowest exposure concentrations (Lebrun et al., 2011).

For metals, it has long been thought that dissolved concentrations in water or even better, the ionic fraction, were more representative of the fraction available for aquatic organisms than the total concentrations in water (Meylan et al., 2004; Niyogi and Wood, 2004). We are now aware that metal bioavailability should be considered differently for each type of plant or animal. For example, bryophytes accumulate more labile than dissolved $\mathrm{Cu}$, whereas freshwater mussels also accumulate particulate metals (Bourgeault et al., 2010; Ferreira et al., 2009). In this study, Cu and Mn bioaccumulations in gammarids were better correlated to total metal concentrations than dissolved metals in freshwaters (Fig. 4). This might be 
explained by an uptake of metals that may be associated with the suspended matter or by a dissociation of metals weakly complexed with organic molecules in contact with the biological cells of animals. For example, $\mathrm{Cu}$ bioaccumulation in periphyton has been shown to be controlled by weakly complexed $\mathrm{Cu}$ in natural freshwaters, unlike $\mathrm{Zn}$ (Meylan et al., 2004).

\subsection{Factors affecting metal bioaccumulation}

The biodynamic and saturation models made it possible to estimate net bioaccumulation of essential metals by $G$. pulex with a factor less than 2 in most cases in environmental conditions. Nevertheless, we obtained relative standard deviations between metal concentrations measured in indigenous gammarids and those predicted by best fittings of the bioaccumulation models of $20.9 \%(0.3-98.9 \%)$ for $\mathrm{Cu}, 38.8 \%(4.4-178.5 \%)$ for $\mathrm{Mn}$ and $151.7 \%(3.3-591.1 \%)$ for $\mathrm{Zn}$. These results highlight that only taking into account the contamination levels of freshwaters is insufficient to explain the bioaccumulation of essential metals by gammarids and this process depends on other environmental factors. In particular, differences in water physicochemistry between sampling sites can be responsible for this variability of bioaccumulation observed in situ (Verschoor et al., 2012). Indeed, it has been reported that varying temperature, $\mathrm{pH}$ or cationic composition in exposure media affect the bioaccumulation of various metals, whether or not they are essential , in crustaceans including G. pulex (Komjarova and Blust, 2009; Lebrun et al., 2011; Pellet et al., 2009). We therefore performed statistical analyses in order to demonstrate, from the field data, major physicochemical variables likely to modulate metal bioaccumulation in indigenous gammarids. Pearson correlation coefficients between these variables and essential metal contents in gammarids are given in Table 1. The results showed that the physicochemical variables tested in this study had very little effect on Mn bioaccumulation in G. pulex, which was closely related to freshwater contamination levels (PCC $=0.88$ and 0.79 for total and dissolved $\mathrm{Mn}$ with $P<0.05)$. By contrast, $\mathrm{Cu}$ and $\mathrm{Zn}$ bioaccumulations in indigenous gammarids were affected by environmental variables.

Significant positive correlations were established between $\mathrm{Cu}$ or $\mathrm{Zn}$ contents in gammarids and $\mathrm{Na}, \mathrm{K}$ or $\mathrm{Cl}$ concentrations in freshwaters, which were closely related to conductivity. Thus, $\mathrm{Cu}$ and $\mathrm{Zn}$ contents seem to increase in waters exhibiting elevated conductivity, which could lead to a displacement of base levels. Indeed, both these ions and metals are closely involved in the maintenance of cellular homeostasis of organisms (Bossuyt and Janssen, 2005). Such an increase in internal $\mathrm{Cu}$ was observed with increasing $\mathrm{Na}$ in exposure media in D. magna and G. pulex, but it was not significant (Komjarova and Blust, 2009; Lebrun et al., 2012). Furthermore, statistical analyses showed negative effects of $\mathrm{pH}$ on $\mathrm{Cu}$ bioaccumulation. Such suppressive effects of $\mathrm{pH}$ on $\mathrm{Cu}$ uptake have been reported in freshwater moss and D. magna (Ferreira et al., 2009; Komjarova and Blust, 2009). Although these statistical results offer the possibility to identify, from field data, major physicochemical factors likely to affect metal bioaccumulation in G. pulex, their formalization remains difficult in such complex and variable environmental conditions. Characterizing their action mechanisms in laboratory conditions should thus allow explaining, at least in part, the interpopulation variability of bioaccumulation observed in situ. This corroborates the growing concept to consider water chemistry in setting environmental guidelines for risk assessment of metals (Niyogi and Wood, 2004; Peters et al., 2011).

The Seine basin is mainly dominated by carbonate rocks and consequently, all freshwaters of the basin are classified as very hard because of elevated concentrations of $\mathrm{Mg}$ (4-26 $\mathrm{mg} / \mathrm{L})$ and $\mathrm{Ca}(70-204 \mathrm{mg} / \mathrm{L})$. These hardness cations are usually reported to compete on transport sites with metals such as $\mathrm{Zn}, \mathrm{Ni}, \mathrm{Cd}$ or $\mathrm{Pb}$, thus reducing their uptake by aquatic organisms including gammarids (Bourgeault et al., 2010; Komjarova and Blust, 2009; Lebrun et al., 2011; Pellet et al., 2009). However, in this field study, only Ca had a significant inhibitive effect on $\mathrm{Zn}$ bioaccumulation in indigenous populations of gammarids. In the case 
of $\mathrm{Cu}$, the absence of an effect of $\mathrm{Ca}$ and $\mathrm{Mg}$ on its bioaccumulation has been demonstrated in G. pulex exposed in laboratory conditions, since this metal would take preferentially membrane $\mathrm{Na}$ channels rather than $\mathrm{Mg}$ and $\mathrm{Ca}$ channels, unlike $\mathrm{Zn}$ (Lebrun et al., 2012; Niyogi and Wood, 2004). In the case of $\mathrm{Mn}$, it is probable that $\mathrm{Ca}$ and $\mathrm{Mg}$ have reached their maximal protective effects insofar as all freshwaters exhibit high water hardness (>180 mg/L $\mathrm{CaCO}_{3}$ ), as observed in fish exposed to elevated concentrations of Mn (Peters et al., 2011). This confirms the importance of regarding the geochemical background of freshwaters in the interpretation of the contamination of indigenous populations inhabiting various and contrasted regions.

\section{Conclusion}

These investigations at the scale of a river basin demonstrate that indigenous populations of the G. pulex species, easily sampled in the field, could be suitable biomonitors of the contamination of freshwaters by essential metals. Indeed, net accumulations of $\mathrm{Zn}, \mathrm{Mn}$ and $\mathrm{Cu}$, i.e. above base levels, were observed for environmentally realistic exposures and reflect annual variations in contamination levels of surrounding environments. Furthermore, field data can be used to relate metal accumulations to contamination levels of freshwaters with different bioaccumulation models. Nevertheless, we also demonstrate that bioaccumulation patterns are specific to each essential metal (base levels, internal regulation and saturation processes). In particular, G. pulex has a maximum capacity to accumulate $\mathrm{Cu}$ insofar as the bioaccumulation process tends to saturate at environmental exposures, unlike $\mathrm{Zn}$ and $\mathrm{Mn}$. Therefore, understanding of the bioaccumulation patterns for each species-metal pair is a crucial step before using bioaccumulation data as an environmental assessment tool and defining the threshold values not to exceed for protecting aquatic biota as required by the EU-WFD. Moreover, the present results highlight the need to understand how other factors, in addition to metal pollution, may affect bioaccumulation because they are potential confounding factors in the interpretation of the contamination of indigenous populations inhabiting heterogenic aquatic environments. This is especially true for $\mathrm{Cu}$ and $\mathrm{Zn}$ bioaccumulation, which appear to be influenced by a complex combination of physicochemical factors.

\section{Acknowledgments}

The authors are sincerely grateful to Aurélie Germain and Pauline Robert-Sainte for their active contribution and to DIREN (Direction Régionale de l'Environnement) for its involvement during the sampling campaigns. We also wish to thank the Région lle-de-France for its financial support.

\section{References}

Atli G, Canli M. Essential metal (Cu, Zn) exposures alter the activity of ATPases in gill, kidney and muscle of tilapia Oreochromis niloticus. Ecotoxicology 2011; 20:1861-69.

Baden SP, Eriksson SP. Role, routes and effects of manganese in crustaceans. Oceanography and Marine Biology - an Annual Review, Vol 44. Crc Press-Taylor \& Francis Group, Boca Raton, 2006, pp. 61-83.

Besse JP, Geffard O, Coquery M. Relevance and applicability of active biomonitoring in continental waters under the Water Framework Directive. Trends Anal Chem 2012; 36:113-127. 
Bisson M, Bureau J, Houeix N, Jolibois B, Gay G, Lefevre JP, et al. French Expertise Report on Manganese. 2011; htpp://www.ineris.fr.

Borgmann U, Couillard Y, Grapentine LC. Relative contribution of food and water to 27 metals and metalloids accumulated by caged Hyalella azteca in two rivers affected by metal mining. Environ Pollut 2007; 145:753-765.

Borgmann U, Norwood WP, Dixon DG. Re-evaluation of metal bioaccumulation and chronic toxicity in Hyalella azteca using saturation curves and the biotic ligand model. Environ Pollut 2004; 131:469-484.

Bossuyt BTA, Janssen CR. Copper regulation and homeostasis of Daphnia magna and Pseudokirchneriella subcapitata: influence of acclimation. Environ Pollut 2005; 136:135-144.

Bourgeault A, Gourlay-France C, Tusseau-Vuillemin MH. Modeling the effect of water chemistry on the bioaccumulation of waterborne cadmium in zebra mussels. Environ Toxicol Chem; 2010; 29:2182-2189.

Clason B, Zauke GP. Bioaccumulation of trace metals in marine and estuarine amphipods: evaluation and verification of toxicokinetic models. Can J Fish Aquat Sci 2000; $57: 1410-1422$.

Comber SDW, Merrington G, SturdyL, Delbeke K, van Assche F. Copper and zinc water quality standards under the EU Water Framework Directive: The use of a tiered approach to estimate the levels of failure. Sci Total Environ 2008; 403:12-22.

Croteau MN, Luoma SN. Characterizing dissolved $\mathrm{Cu}$ and $\mathrm{Cd}$ uptake in terms of the biotic ligand and biodynamics using enriched stable isotopes. Environ Sci Technol 2007; 41:3140-3145.

Directive 2008/105/EC. Directive of the European Parliament and the Council of the European Union for environmental quality standards in the field of water policy (WFD). Official Journal of European Communities.

Ferreira D, Ciffroy P, Tusseau-Vuillemin M-H, Garnier C, Garnier J-M. Modelling exchange kinetics of copper at the water-aquatic moss (Fontinalis antipyretica) interface: Influence of water cationic composition ( $\mathrm{Ca}, \mathrm{Mg}, \mathrm{Na}$ and $\mathrm{pH}$ ). Chemosphere 2009; 74:1117-1124.

Fialkowski W, Rainbow PS, Smith BD, Zmudzinski L. Seasonal variation in trace metal concentrations in three talitrid amphipods from the Gulf of Gdansk, Poland. J Exp Mar Biol Ecol 2003; 288:81-93.

Fialkowski W, Rainbow PS. The discriminatory power of two biomonitors of trace metal bioavailabilities in freshwater streams. Water Res 2006; 40:1805-1810.

Gaillardet J, Viers J, Dupré B. Trace elements in river waters. In: Holland HD, Turekian KK, editors. Treatise on Geochemistry: Surface and Ground Water, Weathering, and Soils. Elsevier, Amsterdam, 2004, pp. 225-272.

Geffard A, Sartelet H, Garric J, Biagianti-Risbourg S, Delahaut L, Geffard O. Subcellular compartmentalization of cadmium, nickel, and lead in Gammarus fossarum: Comparison of methods. Chemosphere 2010; 78:822-9.

Khan FR, Bury NR, Hogstrand C. Copper and zinc detoxification in Gammarus pulex (L.). J Exp Biol 2012; 215:822-832.

Khan FR, Irving JR, Bury NR, Hogstrand C. Differential tolerance of two Gammarus pulex populations transplanted from different metallogenic regions to a polymetal gradient. Aquat Toxicol 2011; 102:95-103.

Komjarova I, Blust R. Effect of $\mathrm{Na}, \mathrm{Ca}$ and $\mathrm{pH}$ on simultaneous uptake of $\mathrm{Cd}, \mathrm{Cu}, \mathrm{Ni}, \mathrm{Pb}$, and $\mathrm{Zn}$ in the water flea Daphnia magna measured using stable isotopes. Aquat Toxicol 2009; 94:81-86.

Lebrun JD, Perret M, Geffard A, Gourlay-Francé C. Modelling copper bioaccumulation in Gammarus pulex and alterations of digestive metabolism. Ecotoxicology 2012; 21:2022-2030.

Lebrun JD, Perret M, Uher E, Tusseau-Vuillemin MH, Gourlay-France C. Waterborne nickel bioaccumulation in Gammarus pulex. Comparison of mechanistic models and influence of water cationic composition. Aquat Toxicol 2011; 104:161-167. 
Luoma SN, Rainbow PS. Why Is Metal Bioaccumulation So Variable? Biodynamics as a Unifying Concept. Environ Sci Technol 2005; 39:1921-1931.

Maltby L, Crane M. Responses of Gammarus pulex (amphipoda, crustacea) to metalliferous effluents: Identification of toxic components and the importance of interpopulation variation. Environ Pollut 1994; 84:45-52.

McGeer JC, Brix KV, Skeaff JM, DeForest DK, Brigham SI, Adams WJ, et al. Inverse relationship between bioconcentration factor and exposure concentration for metals: Implications for hazard assessment of metals in the aquatic environment. Environ Toxicol Chem 2003; 22:1017-1037.

Meylan S, Behra R, Sigg L. Influence of metal speciation in natural freshwater on bioaccumulation of copper and zinc in periphyton: A microcosm study. Environ Sci Technol 2004; 38:3104-3111.

Niyogi S, Wood CM. Biotic ligand model, a flexible tool for developing site-specific water quality guidelines for metals. Environ Sci Technol 2004; 38:6177-6192.

Norwood WP, Borgmann U, Dixon DG. Saturation models of arsenic, cobalt, chromium and manganese bioaccumulation by Hyalella azteca. Environ Pollut 2006; 143:519-528.

Pellet B, Geffard O, Lacour C, Kermoal T, Gourlay-Francé C, Tusseau-Vuillemin M-H. A model predicting waterborne cadmium bioaccumulation in Gammarus pulex: The effects of dissolved organic ligands, calcium, and temperature. Environ Toxicol Chem 2009; 28:2434-2442.

Peters A, Lofts S, Merrington G, Brown B, Stubblefield W, Harlow K. Development of biotic ligand models for chronic manganese toxicity to fish, invertebrates, and algae. Environ Toxicol Chem 2011; 30:2407-2415.

Rainbow PS. Trace metal bioaccumulation: Models, metabolic availability and toxicity. Environ Internat 2007; 33:576-582.

Roussel $\mathrm{H}$, Chauvet E, Bonzom JM. Alteration of leaf decomposition in copper-contaminated freshwater mesocosms. Environ Toxicol Chem 2008; 27:637-644.

Shuhaimi-Othman M, Nur-Amalina R, Nadzifah Y. Toxicity of metals to a freshwater snail, Melanoides tuberculata. Sci World J 2012; 2012:125785.

Thevenot DR, Moilleron R, Lestel L, Gromaire MC, Rocher V, Cambier P, et al. Critical budget of metal sources and pathways in the Seine River basin (1994-2003) for Cd, Cr, $\mathrm{Cu}, \mathrm{Hg}, \mathrm{Ni}, \mathrm{Pb}$ and $\mathrm{Zn}$. Sci Total Environ 2007; 375:180-203.

Tusseau-Vuillemin M-H, Gourlay C, Lorgeoux C, Mouchel J-M, Buzier R, Gilbin R, et al. Dissolved and bioavailable contaminants in the Seine river basin. Sci Total Environ 2007; 375:244-256.

Uher E, Mirande-Bret C, Gourlay-Francé C. Lessons from a large scale deployment of DGT in the Seine basin. RSC Environ Chem Group Bull 2011; 1:1-8.

Verschoor AJ, Hendriks AJ, Vink JPM, de Snoo GR, Vijver MG. Multimetal accumulation in crustaceans in surface water related to body size and water chemistry. Environ Toxicol Chem 2012; 31:2269-2280.

Xu Q, Pascoe D. The importance of food and water as sources of zinc during exposure of Gammarus pulex (Amphipoda). Arch Environ ContamToxicol 1994; 26:459-465. 
Table 1 : Identification of physicochemical factors affecting the bioaccumulation of $\mathrm{Cu}, \mathrm{Zn}$ and $\mathrm{Mn}$ in indigenous populations of $\mathrm{G}$. pulex by statistical analyses of field data. Pearson correlation coefficients (PCC) were obtained by multiple correlation analysis between internal concentrations and selected physicochemical variables (31 sampling sites; $n=420$ field data). Bold values are significant positive or negative correlations $(P<0.05)$.

\begin{tabular}{|c|c|c|c|}
\hline \multirow[b]{2}{*}{ Variables } & \multicolumn{3}{|c|}{ Internal concentrations } \\
\hline & $\mathrm{Cu}$ & $\mathbf{Z n}$ & Mn \\
\hline Total & 0.70 & 0.48 & 0.88 \\
\hline Dissolved & 0.48 & 0.53 & 0.79 \\
\hline $\mathrm{pH}$ & -0.47 & -0.14 & 0.26 \\
\hline Temperature & 0.31 & -0.10 & -0.17 \\
\hline Conductivity & 0.31 & 0.38 & -0.08 \\
\hline $\mathrm{Na}$ & 0.56 & 0.48 & 0.04 \\
\hline $\mathrm{Cl}$ & 0.55 & 0.37 & 0.02 \\
\hline K & 0.62 & 0.12 & -0.02 \\
\hline $\mathrm{Ca}$ & 0.04 & -0.37 & 0.04 \\
\hline $\mathrm{Mg}$ & -0.32 & -0.20 & -0.03 \\
\hline $\mathrm{CO} 3$ & -0.01 & -0.24 & -0.06 \\
\hline $\mathrm{SO} 4$ & 0.01 & -0.02 & 0.18 \\
\hline
\end{tabular}




\section{Figures}

Fig. 1. Map of the Seine basin showing the sites sampled in summers 2008 (circles) and 2009 (squares). The freshwaters conserved for interannual comparisons are indicated by a number: Sausseron (1), Prédecelle (2) Misery (3) and Essone (4).

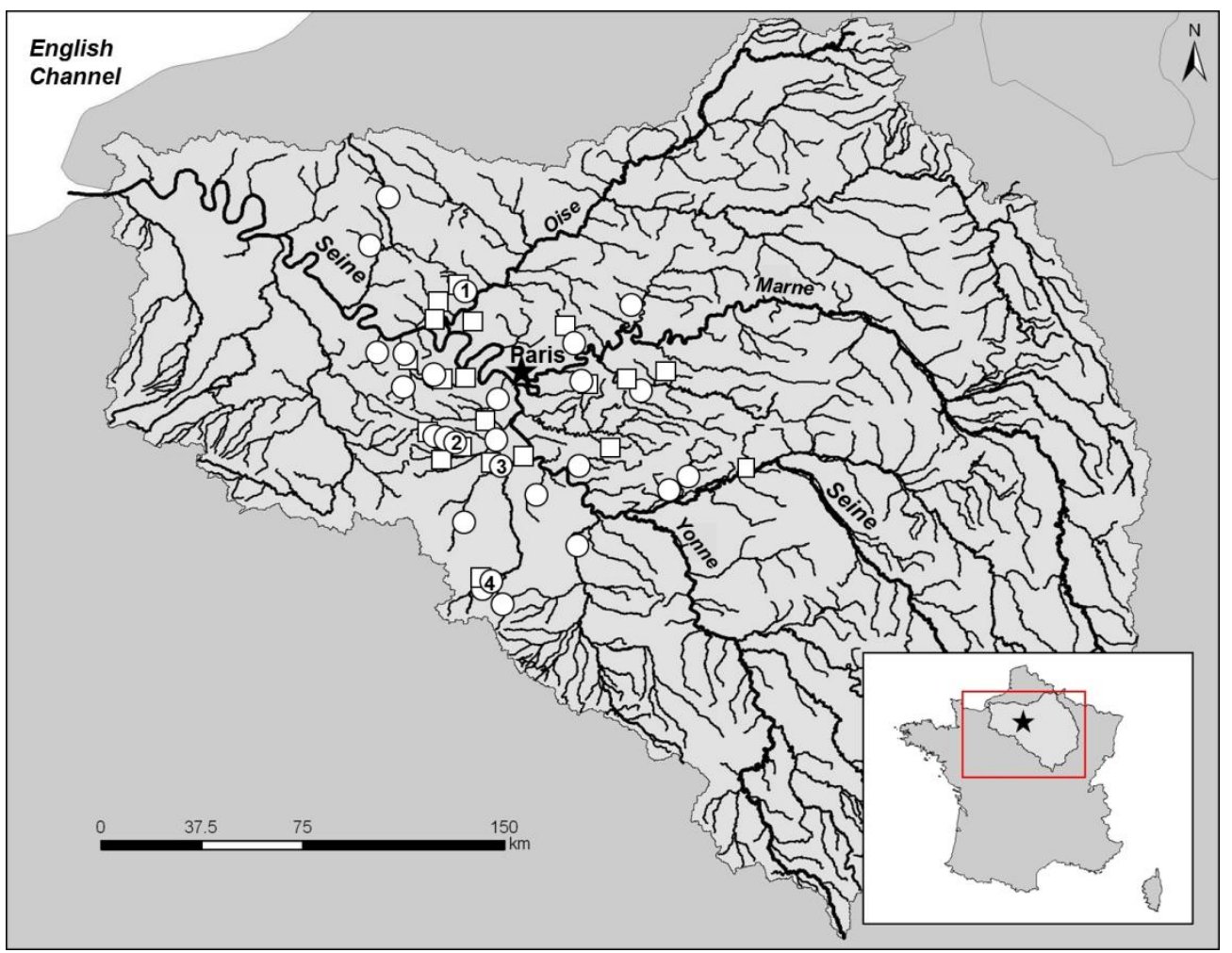


Fig. 2. Ranges of total and dissolved metal concentrations in waters (A) and in Gammarus pulex (B) at the Seine basin scale. Black boxes correspond to $50 \%$ of values in which medians are included (38 sampling sites: 24 in summer 2008 and 14 in summer 2009). Grey boxes are minimal and maximal quartiles.
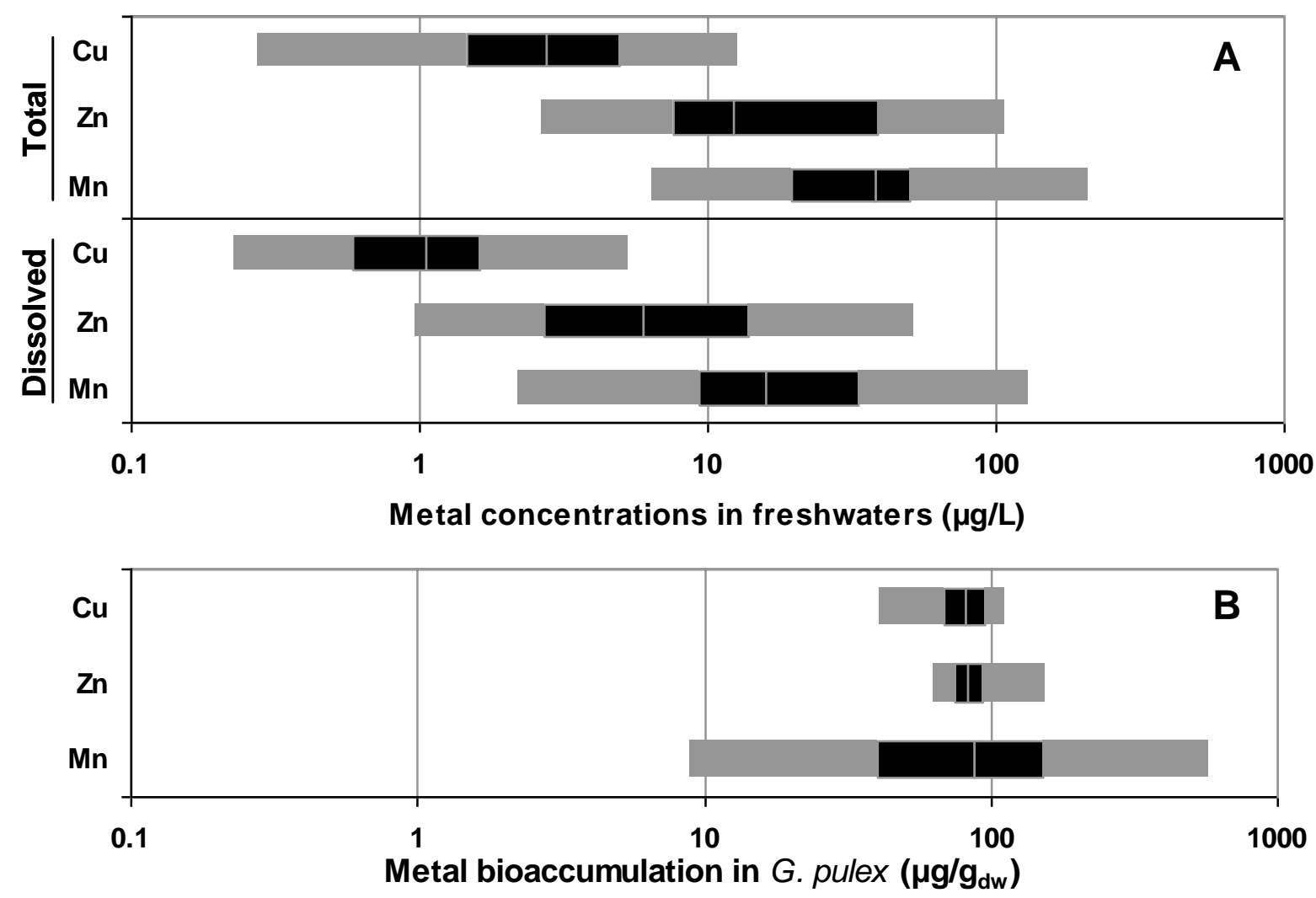
Fig. 3. Relationships between essential metals accumulated by indigenous populations of $G$. pulex and total or dissolved metal concentrations in freshwaters at the Seine basin scale. Symbols are means of 3 or 4 pools of 10 gammarids for each site sampled during summers 2008 and 2009. Dotted lines corresponds to base levels $\pm 95 \%$ confidence intervals.
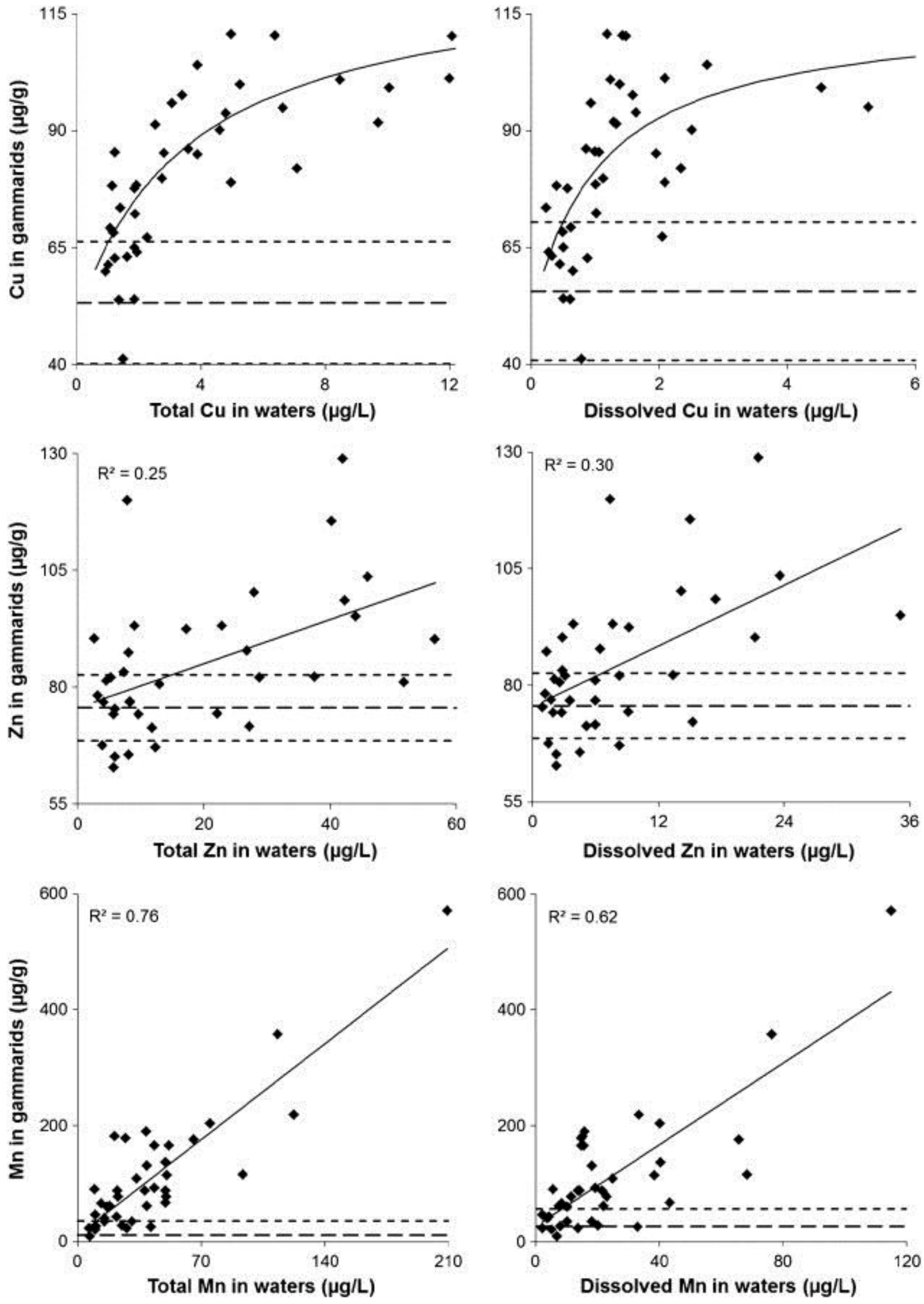
Fig. 4. Bioaccumulation factors of $\mathrm{Cu}, \mathrm{Zn}$ and $\mathrm{Mn}$ in indigenous populations of $\mathrm{G}$. pulex related to exposure levels at the Seine basin scale. Data are on a log-log basis and the best fits from linear regression analysis are shown.
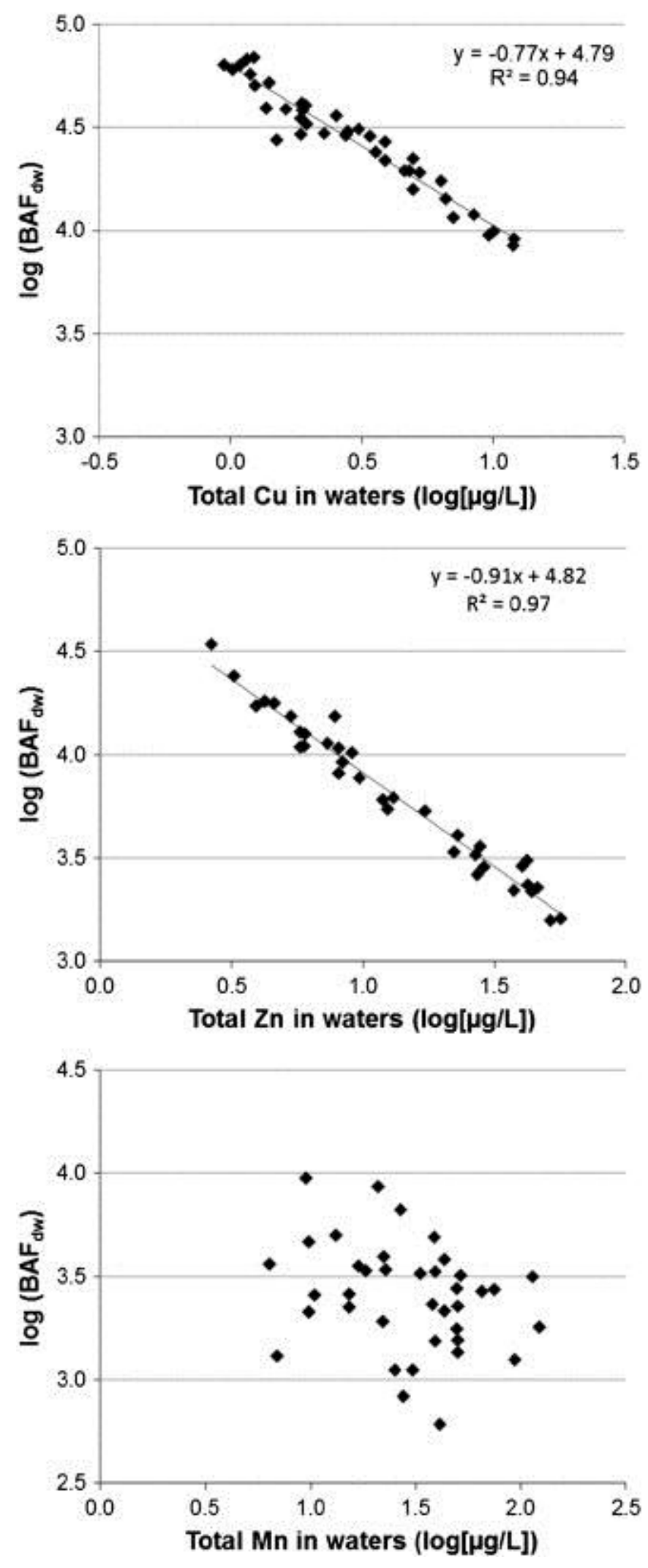
Fig. 5. Annual variations in metal concentrations in Gammarus pulex indigenous populations and in freshwaters. Solid and hatched columns represent indigenous gammarids collected during the 2008 and 2009 campaigns, respectively (values are means of 3 pools of ten individuals $\pm \mathrm{SE}$; * Significant interannual variation in metal concentrations in animals with $P$ $<0.05)$. Symbols with lines are respective total metal concentrations in waters.
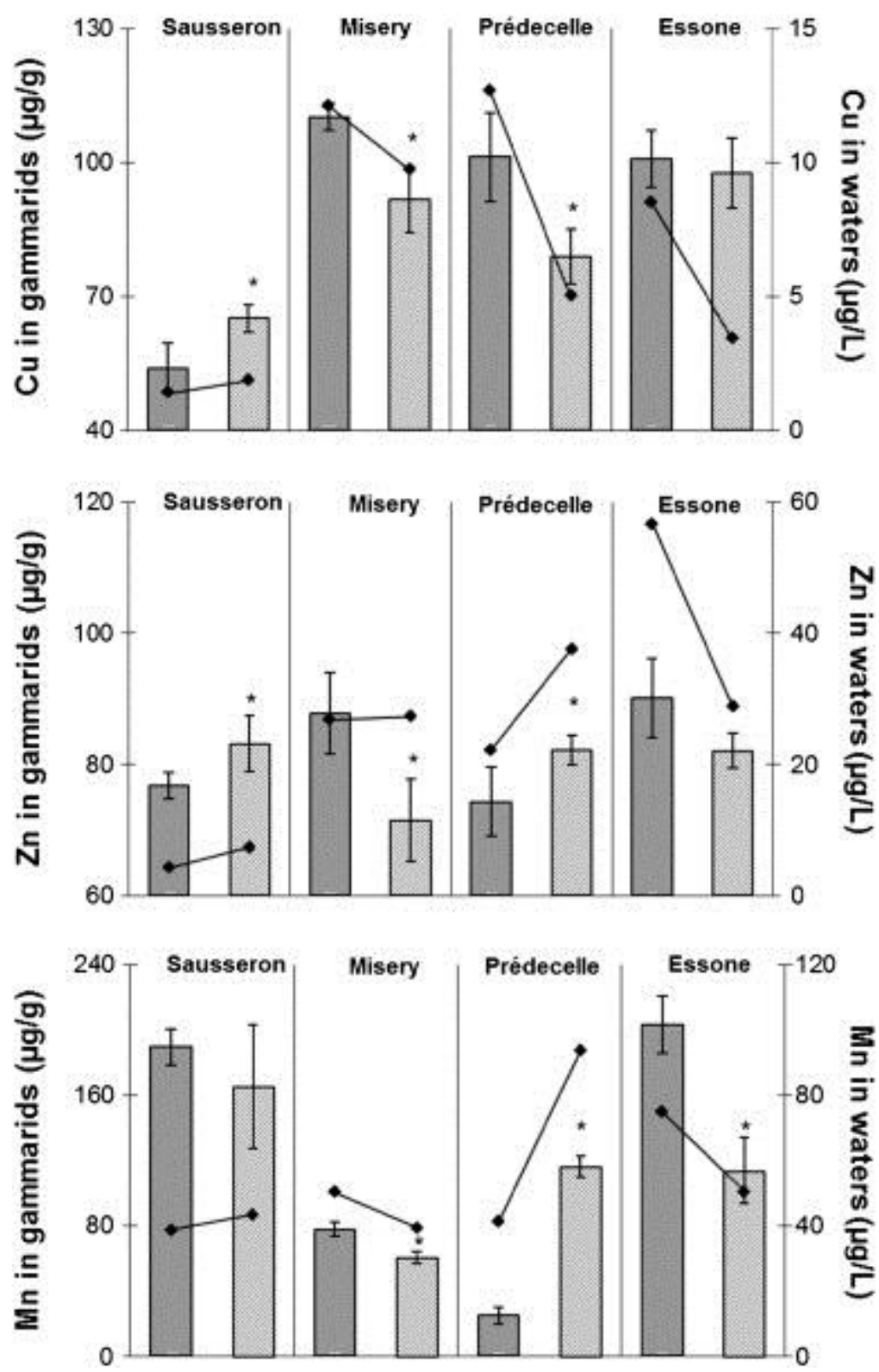